\title{
ANALISIS DAMPAK INFRASTRUKTUR TRANSPORTASI DAN TEKNOLOGI INFORMASI KOMUNIKASI TERHADAP NILAI TUKAR PERDAGANGAN DI ASEAN DAN ASIA TIMUR
}

\author{
Mimik Nurjanti ${ }^{1}$, Dedi Budiman Hakim ${ }^{2}$, dan Sri Mulatsih ${ }^{2}$ \\ ${ }^{1}$ Staf BPS RI \\ ${ }^{2}$ Staf Pengajar FEM IPB
}

\author{
Artikel diterima Januari 2013 \\ Artikel disetujui untuk dipublikasikan Juli 2013
}

\begin{abstract}
The cooperation among ASEAN countries and East Asia countries gives advantage and challenge for each member country. Each country can improve their term of trade through international trade. The aims of this study are to analyze the impact of transportation infrastructure and information communication technology on term of trade in ASEAN countries (consist of Indonesia, Thailand, Singapore, Malaysia, Philipines and Vietnam) and East Asia countries (consist of China, Japan, Hongkong and South Korea). This study used panel yearly data of term of trade, index of transportation infrastructure, cost of export/import, time to export/import, internet user, and export/import of communication devices. Time references were 2006-2011. Statics panel data model was used to determine the relationship between term of trade and these variables for ASEAN and East Asia. Dummy intercept was applied to explain the differences between ASEAN countries and East Asia countries. The results expose that both in ASEAN and East Asia Countries, transportation infrastructure and the export value of communication devices have a positive correlation on the term of trade, whereas cost of export has a negative correlation on term of trade. To increase the term of trade, each country should be improve the quality of transportation infrastructure, increase export of communication devices, and reduce the cost to export.
\end{abstract}

Keywords: term of trade, transportation infrastructure, information/communication devices, static panel data model

\section{PENDAHULUAN}

Salah satu $\begin{array}{r}\text { indikator } \\ \text { perdagangan }\end{array}$
perkembangan internasional suatu negara adalah nilai ekspor dan impornya. Kemampuan mengekspor dan mengimpor yang dilakukan oleh suatu negara akan menentukan nilai tukar perdagangan (term of trade) negara tersebut terhadap negara lainnya. Nilai tukar perdagangan menggambarkan kesejahteraan suatu negara dari perspektif perdagangan internasional. Jika nilai tukar perdagangan meningkat maka hal tersebut mengindikasikan peningkatan posisi perdagangan negara tersebut melalui kemampuan mengekspor dibandingkan dengan impornya. Nilai tukar perdagangan memengaruhi pendapatan riil suatu negara dari sisi perdagangan internasional.

Pertumbuhan ekonomi global merupakan salah satu pendorong munculnya integrasi ekonomi di setiap kawasan. Negara-negara ASEAN (Association of Southeast Asia Nations) membentuk suatu kawasan kerjasama yang besar seperti Eropa dengan European Union dan Amerika dengan NAFTA. Tujuan dibentuknya integrasi 
ekonomi pada dasarnya adalah meningkatkan kesejahteraan setiap negara anggota. Demikian juga tujuan didirikannya ASEAN yaitu meningkatkan kerjasama ekonomi, perdagangan, dan sosial budaya antar negara di kawasan Asia Tenggara. Inti pokok dari kerjasama ekonomi antar negara ASEAN adalah peningkatan lalu lintas perdagangan antar negara anggota ASEAN dengan memberikan perhatian khusus kepada peningkatan kerjasama regional. Selain berupaya mewujudkan integrasi ekonomi antar negara ASEAN, dilakukan juga kerjasama perdagangan dengan negara-negara di luar ASEAN. Kerjasama perdagangan dengan negaranegara di kawasan Asia Timur dipandang strategis karena kawasan Asia Timur dengan jumlah penduduk sekitar 3 milyar dan letak geografis yang berdekatan merupakan pasar yang potensial. Total nilai ekspor dan impor dari negara-negara ASEAN ke Asia Timur selalu mengalami peningkatan dari tahun ke tahun. Terbukanya kerjasama perdagangan yang lebih luas pada negara-negara ASEAN dan Asia Timur semakin menunjukkan luasnya pasar antar negara ASEAN dan Asia Timur. Kerjasama perdagangan akan memberikan keuntungan sekaligus tantangan bagi setiap negara, juga menimbulkan persaingan global yang semakin ketat. Globalisasi membuat pasar antar negara menjadi semakin luas. Negara yang memiliki keunggulan kompetitif semakin dapat memperkaya negaranya dan meningkatkan nilai tukar perdagangannya.

Merujuk pada penelitian yang menyatakan bahwa arus perdagangan di
Asia Tenggara sensitif dipengaruhi oleh sektor infrastruktur transportasi dan teknologi informasi komunikasi, maka diduga keterkaitan faktor-faktor tersebut terhadap arus perdagangan akan memengaruhi nilai perdagangan yang pada akhirnya akan memengaruhi nilai tukar perdagangan. Dugaan tersebut dikuatkan dengan data empiris yang ada. Gambar 1 menunjukkan perbandingan nilai tukar perdagangan untuk negaranegara ASEAN dan Asia Timur tahun 2009. Negara dengan nilai tukar perdagangan yang tinggi adalah China, Singapura, Malaysia, Korea Selatan dan Thailand. Melalui kebijakan peningkatan ekspor, negara-negara tersebut secara signifikan berhasil meningkatkan nilai ekspornya. Nilai tukar perdagangan yang rendah dialami oleh Jepang, Indonesia dan Philipina. Rendahnya nilai tukar perdagangan Jepang disebabkan rendahnya indek nilai ekspor. Nilai ekspor Jepang rendah karena Jepang juga mendirikan pusat industrinya di negara-negara yang menjadi pasar produknya, selain di negara Jepang sendiri, sehingga untuk memasarkan produknya Jepang tidak perlu melakukan ekspor. Indonesia dan Philipina mempunyai nilai tukar perdagangan yang rendah karena indek nilai impornya lebih tinggi daripada indek nilai ekspornya. Tinggi rendahnya nilai tukar perdagangan dipengaruhi oleh nilai ekspor dan nilai impor suatu negara terhadap negara lainnya, sehingga faktor-faktor yang memengaruhi ekspor maupun impor juga akan memengaruhi nilai tukar perdagangan. 


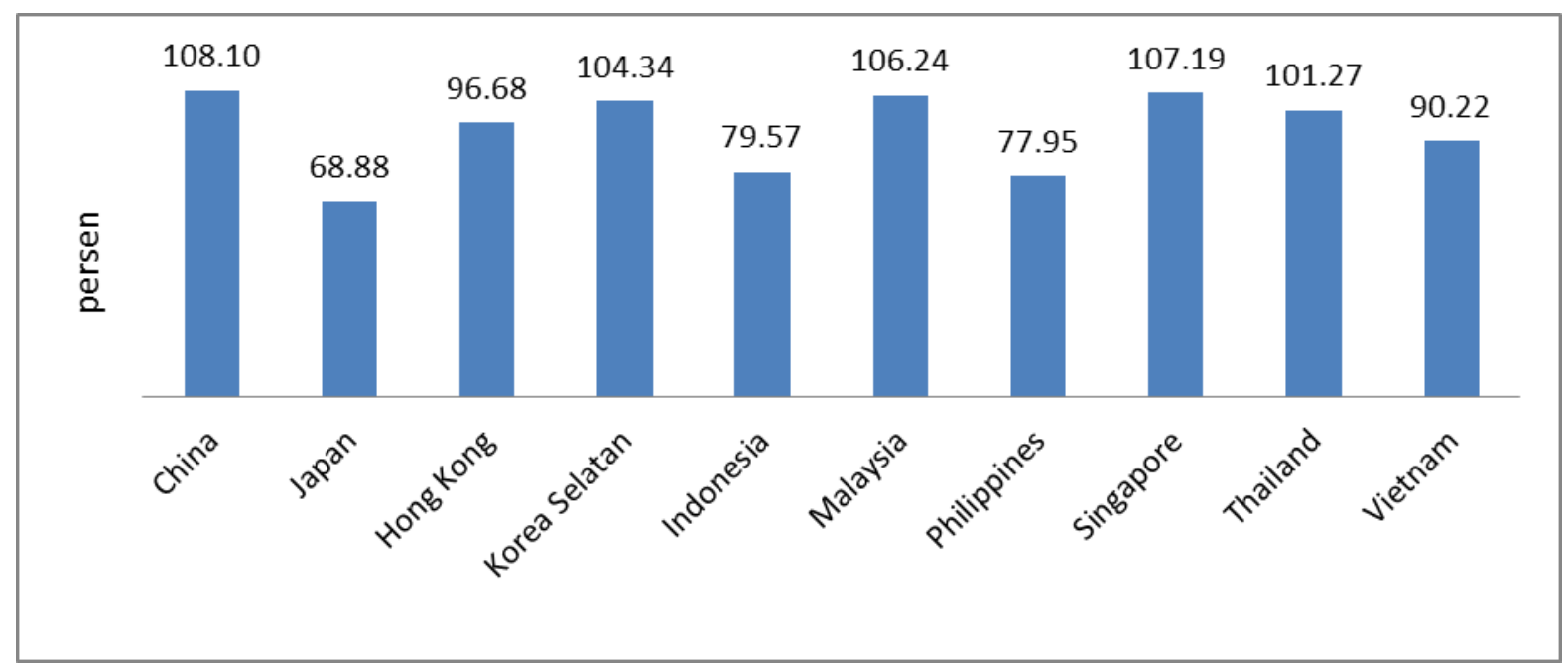

Sumber : World Development Indicators, 2012

\section{Gambar 1. Nilai Tukar Perdagangan Negara-negara ASEAN dan Asia} Timur Tahun 2011 (tahun dasar 2000)

Infrastruktur transportasi memegang peranan yang penting dan strategis dalam menggerakkan roda perdagangan di suatu negara, baik perdagangan lokal maupun perdagangan internasional. Gambar 2 menggambarkan hubungan antara nilai tukar perdagangan dengan indek infrastruktur transportasi di Negara ASEAN dan Asia Timur tahun 2011.

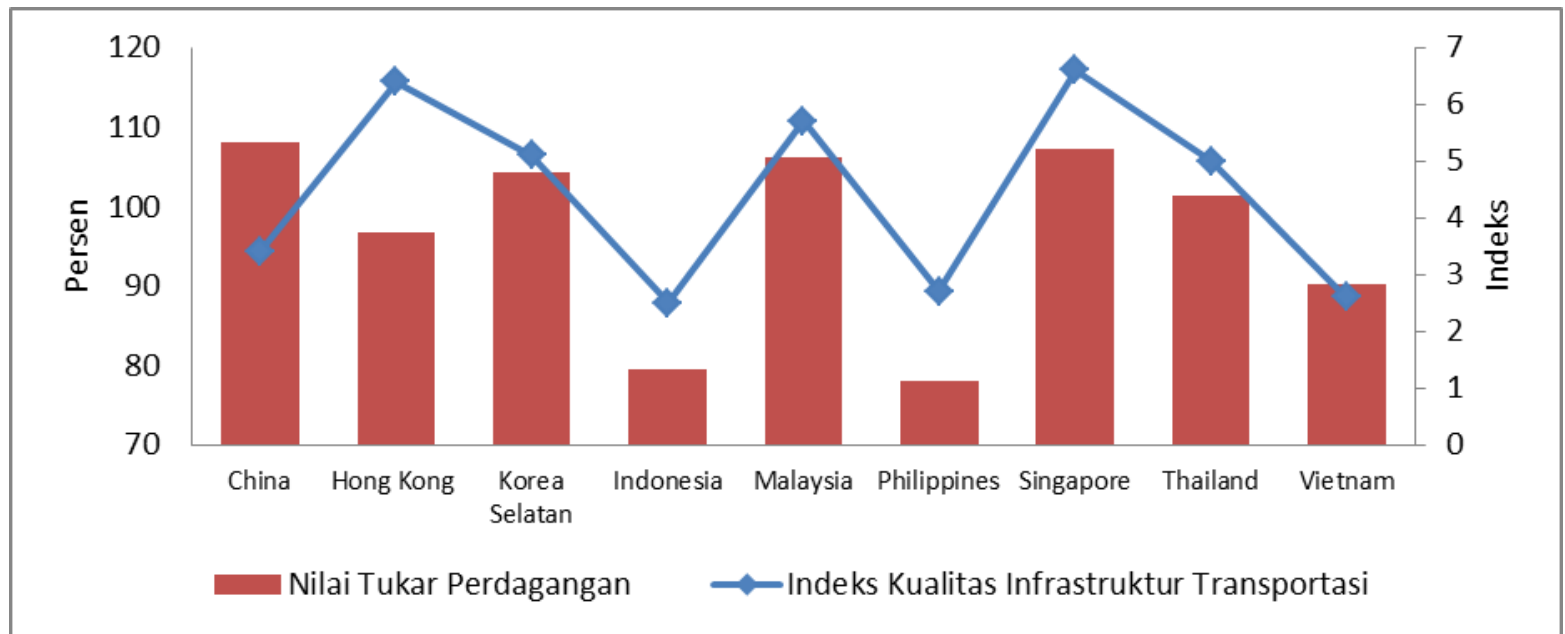

Sumber : World Development Indicators, 2012

\section{Gambar 2. Nilai Tukar Perdagangan dan Indek Kualitas Infrastruktur Transportasi tahun 2011}

Studi ini menggunakan variabel indek infrastruktur transportasi sebagai pendekatan untuk variabel infrastruktur transportasi. Infrastruktur transportasi memengaruhi biaya distribusi barang/jasa. Biaya distribusi memiliki kontribusi yang cukup signifikan dalam total biaya produksi. Kondisi infrastruktur transportasi juga merupakan daya tarik tersendiri bagi investor, yang pada akhirnya akan memengaruhi perekonomian secara luas. 
Kondisi infrastruktur transportasi akan memengaruhi waktu ekspor/impor dan pada akhirnya memengaruhi biaya ekspor/impor. Indonesia, Philipina dan Vietnam dengan indek kualitas infrastruktur transportasi rendah cenderung mempunyai nilai tukar perdagangan yang rendah. Hongkong, Malaysia dan Singapura dengan indek kualitas infrastruktur transportasi tinggi cenderung mempunyai nilai tukar perdagangan yang tinggi. Terdapat hubungan yang positif antara indek kualitas infrastruktur transportasi dengan nilai tukar perdagangan.

Teknologi informasi komunikasi mempunyai peran yang penting terhadap perekonomian. Aplikasi teknologi informasi komunikasi sangat berperan dalam proses penciptaan produk/jasa, aplikasi properti, forwarding, penggudangan, sistem operasi, basis data, network management, sistem akuntansi, penggajian dan keuangan.
Teknologi informasi komunikasi merupakan alat bantu untuk memenangkan persaingan bisnis, efisiensi dan pendorong multiplier efek pertumbuhan ekonomi suatu Negara. Penggunaan teknologi informasi komunikasi mengharuskan ketersediaan barang teknologi informasi komunikasi di suatu Negara. Variabel teknologi informasi komunikasi didekati dengan pengguna internet dan ekspor/impor barang teknologi informasi komunikasi. Gambar 3 menunjukkan hubungan antara nilai tukar perdagangan dengan pengguna internet. Terdapat hubungan positif antara nilai tukar perdagangan dengan pengguna internet. Indonesia dan Philipina dengan pengguna internet yang rendah mempunyai nilai tukar perdagangan yang cenderung rendah. Singapura dan Korea Selatan dengan pengguna internet yang tinggi mempunyai nilai tukar perdagangan yang cenderung tinggi.

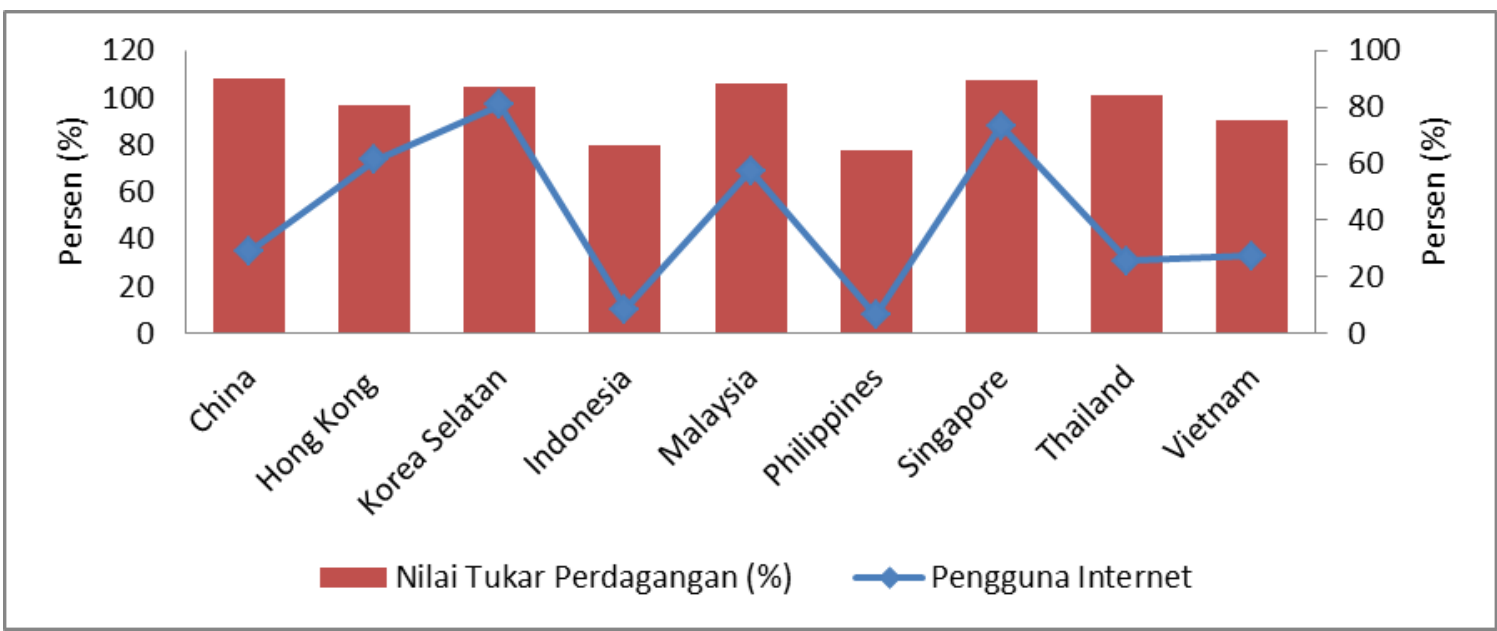

Sumber : World Development Indicators, 2012

\section{Gambar 3. Nilai Tukar Perdagangan dan Pengguna Internet tahun 2011}

Berdasarkan uraian di atas, tujuan dari penelitian in adalah :

1. Menganalisis perkembangan infrastruktur transportasi dan teknologi informasi komunikasi dan nilai tukar perdagangan di Negaranegara ASEAN dan Asia Timur.
2. Menganalisis pengaruh variabel infrastruktur transportasi dan teknologi informasi komunikasi terhadap nilai tukar perdagangan di Negara-negara ASEAN dan Asia Timur 


\section{TINJAUAN LITERATUR}

Freunda dan Weinhold (2004) dengan model gravity meneliti pengaruh internet terhadap perdagangan internasional. Cakupan penelitian terdiri dari 56 negara, mulai tahun 1995 sampai dengan 1999. Model memperlihatkan peningkatan perdagangan karena biaya tetap untuk masuk ke perdagangan internasional semakin murah.

Penelitian Shepherd dan Wilson (2008) mengenai fasilitas perdagangan di negara-negara ASEAN menyatakan bahwa arus perdagangan di Asia Tenggara sensitif di sektor infrastruktur yaitu transportasi dan teknologi informasi komunikasi. Dalam penelitian tersebut, infrastruktur didekati dengan kualitas infrastruktur pelabuhan, kualitas infrastruktur bandar udara dan juga kualitas penyediaan jasa internet. Pendekatan lainnya melalui beberapa faktor yang berkaitan dengan pelaksanaan ekspor dan impor, seperti waktu ekspor/impor, biaya ekspor/impor per kontainer, dan lain sebagainya.

Sen et al, (2009) menerangkan bagaimana variabel ilmu pengetahuan dan teknologi merupakan faktor yang memengaruhi gross terms of trade di negara berkembang dan negara maju. Analisis empiris menggunakan data 22 negara berkembang dan 15 negara maju dari tahun 2001 - 2005. Hasil analisis dengan regresi panel memperlihatkan perubahan variabel ilmu pengetahuan dan teknologi lebih signifikan menjelaskan terms of trade dan ekspor neto negara maju. Studi memasukkan variabel non teknologi (pertumbuhan ekonomi, penanaman modal asing, kredit domestik untuk swasta, suku bunga riil, inflasi, real effective exchange rate), model lebih baik dalam menjelaskan terms of trade negara berkembang, dibandingkan terms of trade negara maju. Efek dari variabel ilmu pengetahuan dan teknologi sangat berpengaruh pada kedua kelompok negara.
Penelitian yang dilakukan oleh Albarran et al, (2009) menyatakan bahwa investasi di bidang infrastruktur transportasi dapat menurunkan biaya transportasi terutama untuk perusahaan yang melakukan ekspor di Spanyol. Pada akhirnya, penurunan biaya transportasi membantu perusahaan kecil dan menengah untuk masuk ke dalam pasar ekspor.

Siddiqi dan Vemuri (2009) telah meneliti mengenai pengaruh teknologi informasi komunikasi terhadap volume perdagangan internasional. Penelitian dilakukan untuk 64 negara periode 19852005. Metode panel data digunakan dan dapat disimpulkan bahwa terdapat pengaruh positif dan signifikan infrastruktur teknologi informasi komunikasi dan ketersediaan internet untuk transaksi komersial pada volume perdagangan internasional.

Chung et al, (2010) meneliti pengaruh teknologi informasi komunikasi dalam perdagangan bilateral sayuran dan buah antara negara anggota APEC periode 1997-2006. Penggunaan internet dan telepon selular merupakan variabel yang diteliti. Hasil studi menunjukkan bahwa menggunakan teknologi informasi komunikasi digital memiliki efek positif yang signifikan pada perdagangan buah dan sayuran antara negara-negara APEC.

\section{KERANGKA PEMIKIRAN}

Kerjasama perdagangan antara negara ASEAN dengan mitra dagangnya Asia Timur terus berlangsung. Penelitian ini dilakukan untuk melihat sejauh mana pengaruh infrastruktur transportasi dan teknologi informasi komunikasi terhadap nilai tukar perdagangan dua kelompok negara. Infrastruktur transportasi memengaruhi waktu ekspor/impor dan pada akhirnya memengaruhi biaya ekspor/impor. Penggunaan barangbarang teknologi informasi komunikasi memberi kemudahan akses informasi dan berpengaruh terhadap biaya 
ekspor/impor. Biaya ekspor/impor memengaruhi volume dan nilai ekspor/impor yang pada akhirnya memengaruhi nilai tukar perdagangan. Gambar 4 menggambarkan kerangka pemikiran penelitian.

1. Internet

2. Ekspor/Impor Barang Teknologi Informasi

Komunikasi

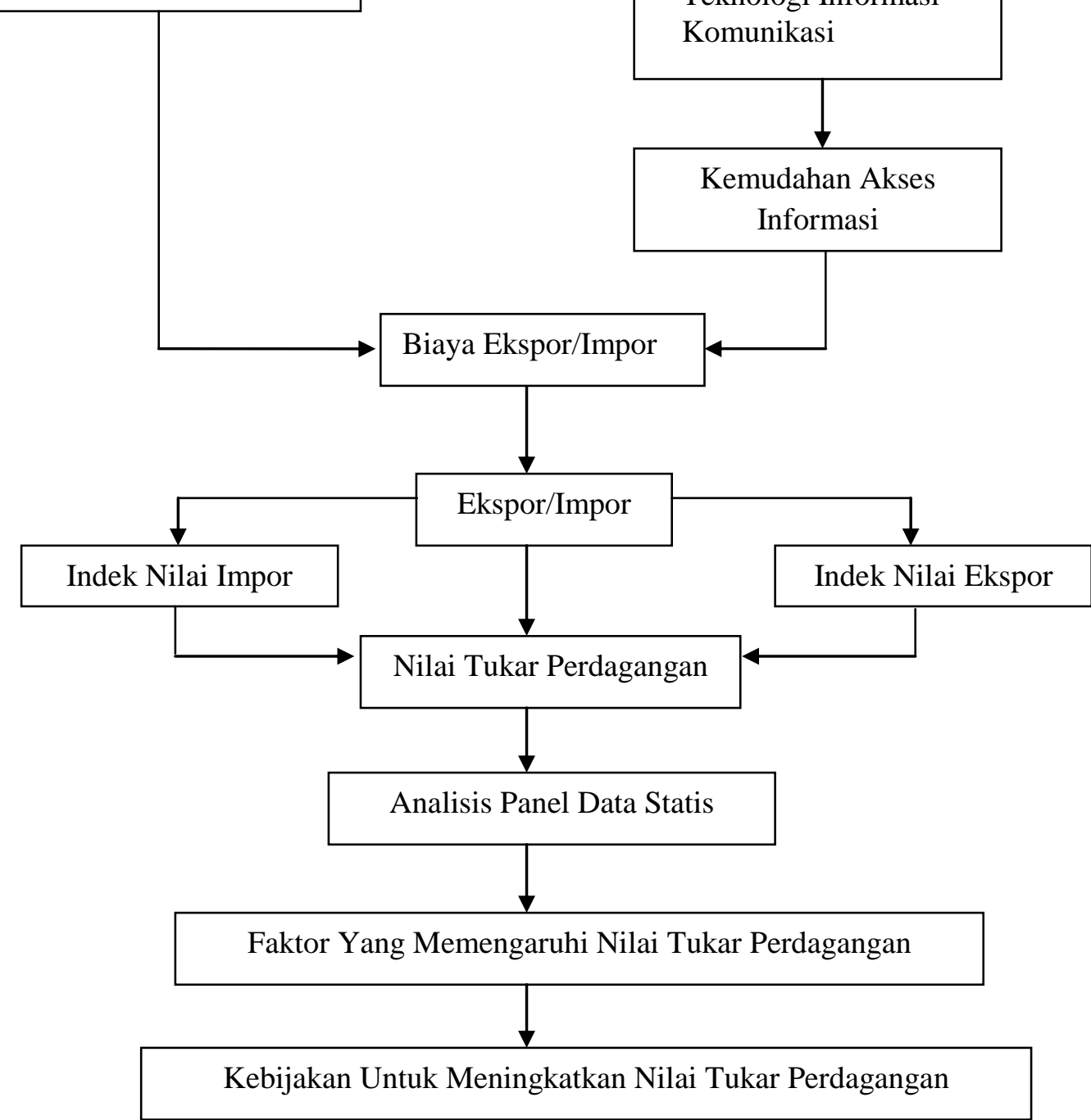

Gambar 4. Kerangka Pemikiran Penelitian

\section{METODE PENELITIAN}

\section{Jenis dan Sumber Data}

Data yang digunakan dalam penelitian ini terdiri dari data infrastruktur transportasi (indek infrastruktur transportasi, biaya ekspor, biaya impor, waktu ekspor dan waktu impor) serta data teknologi informasi komunikasi (pengguna internet, ekspor dan impor barang-barang teknologi informasi komunikasi). Sumber utama data berasal dari COMTRADE, World Development Indicator, Global Competitiveness Report, dan Doing Business - World Bank. Data yang digunakan merupakan data tahunan periode 2006-2011. Negara ASEAN yang diteliti adalah Indonesia, Malaysia, Philipina, Thailand, Singapura, dan 
Vietnam. Sedangkan negara Asia Timur yang diteliti adalah China, Jepang, Hongkong dan Korea Selatan.

\section{Metode Analisis}

Analisis deskriptif digunakan untuk mendeskripkan perkembangan variabel-variabel di negara yang diteliti. Hubungan variabel infrastruktur transportasi dan teknologi informasi komunikasi dianalisis dengan menggunakan persamaan ekonometrik panel data statis. Tahap pertama analisis ekonometri adalah pemilihan model yang paling valid. Parameter model data panel statis diestimasi dengan menggunakan model pooled Least Square, Fixed Effect Model dan Random Effect Model. Dari hasil estimasi ketiga model tersebut dilakukan beberapa uji asumsi untuk melihat model yang lebih valid diantara ketiganya. Uji-uji tersebut antara lain: (i) uji Chow untuk menentukan model yang lebih valid antara model pooled Least Square dengan Fixed Effect Model; (ii) uji Breusch-Pagan Lagrangian Multiplier untuk menentukan model yang lebih valid antara model pooled Least Square dengan Random Effect Model; serta (iii) uji Hausman untuk menentukan model yang lebih valid antara Fixed Effect Model dan Random Effect Model. Jika model yang terpilih adalah Fixed Effect Model tahap kedua dilakukan uji untuk mendeteksi adanya autokorelasi (uji Wooldridge) dan heteroskedastisitas (uji Wald). Tahap ketiga, berdasarkan hasil tahap pertama dan kedua dilakukan estimasi dengan metode Ordinary Least Square (OLS/LSDV) atau metode Genelized Least Square (GLS)/Weighted Least Square (WLS) atau metode Feasible Genelized Least Square (FGLS).

\section{Spesifikasi Model}

Berdasarkan pertimbangan dari beberapa penelitian terdahulu dan merujuk pada model yang digunakan oleh Sen et al (2009), maka model dinyatakan sebagai berikut :

$$
\begin{aligned}
\mathrm{Y}_{i t}= & \beta_{0}+\beta_{1} \mathrm{IU}_{i t}+\beta_{2} \mathrm{ITCeks}_{i t}+\beta_{3} \mathrm{ICTimp}_{i t}+\beta_{4} \mathrm{II}_{i t}+\beta_{5} \mathrm{CE}_{i t}+\beta_{6} \mathrm{CI}_{i t}+\beta_{7} \mathrm{TE}_{i t}+ \\
& \beta_{8} \mathrm{TI}_{i t}+\beta_{9} \mathrm{D}+\varepsilon \ldots \ldots \ldots \ldots \ldots \ldots \ldots \ldots \ldots \ldots \ldots \ldots \ldots \ldots \ldots \ldots \ldots \ldots \ldots \ldots \ldots \ldots \ldots \ldots \ldots \ldots \ldots \ldots \ldots \ldots \ldots \ldots
\end{aligned}
$$

II : Indek kualitas infrastruktur

dimana :

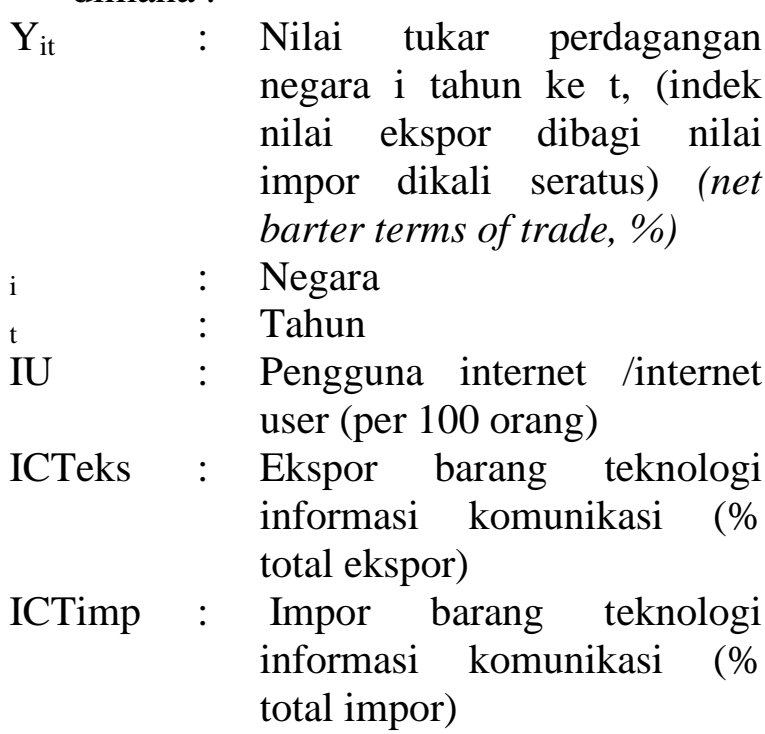
(1=rendah, 7 =sesuai standar internasional)

CE : Biaya (cost) ekspor per container (USD)

CI : Biaya (cost) impor per container (USD)

TE : Waktu ekspor (hari)

TI : Waktu impor (hari) 
estimasi yang disajikan merupakan hasil dari tiga metode estimasi, yaitu pooled least square, fixed effect model (FEM) dan random effect model (REM). Uji Chow menguji antara model pooled least square dengan fixed effect model. Hasil uji Chow menunjukkan nilai statistik (9.73) signifikan pada taraf nyata $1 \%$. Hal ini menunjukkan bahwa pooled least square lebih dipilih dibandingkan fixed effect model. Pemilihan model pooled least square diperkuat dengan $\mathrm{R}$-square dalam model pooled least square sebesar $74.48 \%$ lebih tinggi daripada dalam model fixed effect yang hanya sebesar $5.82 \%$.

Tahap berikutnya adalah melakukan Uji Breusch Pagan. Uji Breusch Pagan menguji antara pooled least square dengan random effect model. Hasil uji Breusch Pagan menunjukkan P-value yang tidak signifikan, artinya random effect model (REM) lebih dipilih daripada pooled least square. Hasil ini diperkuat dengan $\mathrm{R}$-square dalam random effect model sebesar $74.48 \%$. Hal tersebut mengindikasikan bahwa $74.48 \%$ variabel bebas yang diteliti memengaruhi variabel terikatnya. 26.52\% lainnya dipengaruhi variabel lain yang tidak terdapat dalam model. Untuk lebih menyakinkan lagi bahwa model yang valid adalah random effect model dilakukan Uji Hausman. Uji Hausman menguji antara fix effect model dengan random effect model. Hasil Uji Hausman menunjukkan random effect model lebih valid daripada fix effect model. Hal ini ditunjukkan dengan Prob $\mathrm{chi}^{2}=0$ dengan $\mathrm{b}=$ random dan $\mathrm{B}=$ fixed.

Hasil estimasi random effect model menunjukkan bahwa variabel infrastruktur transportasi dan teknologi informasi komunikasi yang memengaruhi nilai tukar perdagangan di negara-negara ASEAN dan Asia Timur adalah variabel ekspor barang teknologi informasi komunikasi, indek infrastruktur transportasi, biaya ekspor per kontainer. Variabel ekspor barang teknologi informasi komunikasi dan indek infrastruktur transportasi signifikan pada taraf nyata $10 \%$. Variabel biaya ekspor per kontainer signifikan pada taraf nyata $1 \%$.

Ekspor barang teknologi informasi komunikasi merupakan persentase ekspor barang teknologi informasi komunikasi terhadap total ekspor suatu negara. Barang teknologi informasi komunikasi yang dimaksud meliputi komputer dan peralatan terkait, alat telekomunikasi dan peralatan terkait, audio video dan peralatan terkait, komponen elektronik, dan barang teknologi komunikasi informasi lainnya kecuali software. Kelebihan ekspor barang teknologi informasi komunikasi adalah harga komoditi ekspor barang teknologi informasi komunikasi tidak ditentukan secara internasional. Harga komoditi ekspor barang teknologi informasi komunikasi ditentukan oleh negara pengekspor. Harga tergantung spesifikasi barang dan teknologi yang ditawarkan. Berbeda dengan harga komoditi ekspor barang sumber daya alam (resources base) seperti barang tambang (minyak bumi, timah, nikel, batubara, dan lain-lain). Harga barang natural resources base sudah ditentukan secara internasional.

Di negara ASEAN dan Asia Timur, ekspor barang teknologi informasi komunikasi berpengaruh positif terhadap nilai tukar perdagangan. Peningkatan $1 \%$ ekspor barang teknologi informasi komunikasi akan meningkatkan nilai tukar perdagangan $0,6 \%$, ceteris paribus. China melakukan percepatan industrialisasi dengan program Silicon Valley. Kementerian Sains dan Teknologi China mengimplementasikan tujuh kunci sektor teknologi tinggi yaitu IT (information technology), bioteknologi, otomasi, energi, material baru, dan dua di bidang militer.

Infrastruktur transportasi meliputi bandar udara (transportasi udara), 
pelabuhan (transportasi laut), jalan, jalan kereta api, jumlah kendaraan bermotor dan jalur air bernavigasi. Secara statistik, indek infrastruktur transportasi sangat berpengaruh terhadap nilai tukar perdagangan. Indek infrastruktur transportasi menggambarkan kondisi infrastruktur transportasi di suatu negara. Indek bernilai antara 1 sampai dengan 7 . Indek 1 menyatakan kualitas infrastruktur transportasi yang rendah. Indek 7 menyatakan kualitas infrastruktur transportasi yang sesuai dengan standar internasional. Di negara ASEAN dan Asia Timur indek infrastruktur transportasi berpengaruh positif terhadap nilai tukar perdagangan. Peningkatan 1 indek akan menyebabkan peningkatan nilai tukar perdagangan sebesar $4.01 \%$, ceteris paribus. Hal ini mengindikasikan bahwa nilai tukar perdagangan sangat dipengaruhi oleh kondisi infrastruktur transportasi.

Infrastruktur transportasi merupakan stimulus/katalis bagi kegiatan perekonomian. Infrastruktur transportasi yang baik dan memadai dapat memperlancar arus barang dan jasa dalam proses produksi. Hal tersebut dapat menyebabkan efisiensi di segala aspek. Singapura dan Jepang memiliki infrastruktur transportasi yang sangat maju. Kondisi infrastruktur transportasi menggambarkan kemajuan suatu negara.

Di negara ASEAN dan Asia Timur, biaya ekspor berpengaruh negatif terhadap nilai tukar perdagangan. Peningkatan 1 USD biaya ekspor akan menurunkan nilai tukar perdagangan sebesar $0.08 \%$, ceteris paribus. Biaya ekspor memberikan pengaruh pada harga komoditi ekspor secara keseluruhan. Biaya ekspor yang dimaksud dalam penelitian ini adalah biaya yang dikenakan pada sebuah kontainer 20 feet dalam dolar Amerika Serikat. Termasuk semua biaya yang terkait dalam penyelesaian prosedur ekspor barang. Dalam hal ini termasuk biaya untuk dokumen, biaya administratif untuk kepabeanan dan pengawasan teknis, biaya bea pialang, biaya penanganan terminal dan transportasi. Biaya tidak termasuk tarif atau pajak perdagangan.

\section{KESIMPULAN DAN SARAN}

Model regresi data panel statis menunjukkan variabel infrastruktur transportasi berpengaruh terhadap nilai tukar perdagangan baik di kawasan ASEAN maupun Asia Timur. Temuan yang sama terjadi pada variabel ekspor barang teknologi informasi komunikasi dan variabel biaya eskpor. Kenaikan variabel ekspor barang teknologi informasi komunikasi menyebabkan kenaikan nilai tukar perdagangan di negara ASEAN dan Asia Timur. Kenaikan variabel indek infrastruktur transportasi menyebabkan kenaikan nilai tukar perdagangan di negara ASEAN dan Asia Timur. Kenaikan variabel biaya ekspor menyebabkan penurunan nilai tukar perdagangan di negara ASEAN dan Asia Timur.

Berdasarkan kesimpulan, maka disarankan adnya perbaikan infrastruktur transportasi untuk negara ASEAN maupun Asia Timur karena dapat meningkatkan nilai tukar perdagangan. Ekspor barang teknologi informasi komunikasi dalam negeri maupun untuk keperluan ekspor perlu ditingkatkan untuk memperbaiki nilai term of trade. Diperlukan upaya-upaya efisien agar biaya ekspor lebih murah dan rasional.

\section{DAFTAR PUSTAKA}

Albarran, P. Carrasco, R. and Holl, A. 2009. Transport Infrastructure, Sunk Costs and Firms' Export Behavior. Working Paper 09-22, Economic Series (13). Departamento de Economía, Universidad Carlos III de Madrid, Calle Madrid, 126, 28903 Getafe.

[ASEAN] Association of Southeast Asian Nation. 2009. ASEAN 
Statistical Year Book 2008. Jakarta : ASEAN

Chung, KC. Fleming, EM. and Fleming, P. 2010. Evaluating the Impacts of Information and Communication Technology (ICT) on Trade in Fruit and Vegetables within the APEC Countries. 2010 Conference (54th), February 10-12, 2010, Adelaide, Australia.

[COMTRADE] United Nations Comodity Trade Statistical Database.

https://wits.worldbank.org/WITS/ WITS/Restricted/Login.aspx [diakses Mei 2011].

Hsiao, C. 2003. Analysis of Panel Data. Second edition. Cambridge University Press.

Firdaus M, Irawan T. 2009. Panel Data Analysis. [module]. Bogor. IRSA.

Freunda, C. Weinhold, D. 2004. The Effect of Internet on International Trade. The American Economic Reviews 92:236-240

Salvatore, D. 1997. Ekonomi Internasional. Edisi Kelima.
Penerjemah Haris Munandar. Jakarta : Erlangga.

Sen, A. Celebioglu, F. and Altay, H. 2009. The Effect of Knowledge and Technology Variables on Terms of Trade. Journal of Faculty Economics and Administrative Sciences, 142:361-374.

Shepherd, B. and Wilson, JS. 2008. Trade Facilitation in ASEAN Member Countries : Measuring Progress and Assessing Priorities, Policy Research Working Paper 20433. The World Bank 1818 H St. NW, Washington D.C.

Vemuri, VK. and Siddiqi, S. 2009. Impact of Commercialization of the Internet on International Trade : A Panel Study Using the Extended Gravity Model. The International Trade Journal, Volume 23, Issue 4, Pages 458484.

DOI: $10.1080 / 08853900903223792$

World Development Indicators. http://data.worldbank.org/indicat or [diakses Mei 2012]. 


\section{Lampiran:}

Tabel 1. Hasil Estimasi Koefisien Model Data Panel Statis.

\begin{tabular}{|c|c|c|c|c|c|c|}
\hline \multirow[t]{3}{*}{ Variabel } & \multicolumn{6}{|c|}{ Model Statis } \\
\hline & \multicolumn{2}{|c|}{ Pooled LS } & \multicolumn{2}{|c|}{ FEM } & \multicolumn{2}{|c|}{ REM } \\
\hline & Koefisien & SE & Koefisien & SE & Koefisien & SE \\
\hline Konstanta & $108,43 * * *$ & 17,76 & $117,78 * * *$ & 28,21 & $108,43 * * *$ & 17,76 \\
\hline Pengguna Internet (IU) & $-0,07$ & 0,15 & $-0,22$ & 0,25 & $-0,07$ & 0,15 \\
\hline $\begin{array}{l}\text { Informasi Komunikasi } \\
\text { (ICTeks) }\end{array}$ & $0,60 *$ & 0,33 & $-0,41$ & 0,56 & $0,6^{*}$ & 0,33 \\
\hline $\begin{array}{l}\text { Informasi Komunikasi } \\
\text { (ICTimp) }\end{array}$ & $-0,56$ & 0,46 & 0,41 & 0,55 & $-0,56$ & 0,46 \\
\hline Indek Infrastruktur (II) & $4,01^{*}$ & 2,28 & $-3,25$ & 5,49 & $4,01 *$ & 2,28 \\
\hline Biaya Ekspor (CE) & $-0,08 * * *$ & 0,02 & $-0,01^{\mathrm{TS}}$ & 0,02 & $-0,08 * * *$ & 0,02 \\
\hline Biaya Impor $(\mathrm{CI})$ & 0,02 & 0,02 & 0,01 & 0,02 & 0,02 & 0,02 \\
\hline Waktu Ekspor (TE) & 0,60 & 0,80 & 0,2 & 1,09 & 0,6 & 0,80 \\
\hline Waktu Impor (TI) & $-0,35$ & 0,86 & $-0,07$ & 0,88 & $-0,35$ & 0,86 \\
\hline $\begin{array}{l}\text { Dummy Kelompok } \\
\text { Negara (D) }\end{array}$ & $-6,95$ & 4,64 & & & $-6,95$ & 4,64 \\
\hline Chow F-Test & $9,73 * * *$ & & 0,33 & & & \\
\hline Breusch-Pagan LM Test & & & 0,64 & & & \\
\hline R-squared & $74,48 \%$ & & $5,82 \%$ & & $74,48 \%$ & \\
\hline Adj R-squared & $66,83 \%$ & & & & & \\
\hline
\end{tabular}

*** Signifikan pada taraf nyata $1 \%, * *$ taraf nyata $5 \%, *$ taraf nyata $10 \%$

SE: standar error (kesalahan baku) 